\title{
The Influence of Jinggangshan Spirit on University Ideological and Political Education
}

\author{
Limin Lu \\ Harbin University of Commerce School of Accountancy, Harbin150028, China \\ IIm3187123@sina.com
}

Keywords: Jinggangshan spirit, ideals and beliefs, hard struggle, pioneering and innovative, ideological and political education.

\begin{abstract}
Jinggangshan spirit is a fine tradition formed by the Communist Party of China during the revolutionary practice of the Agrarian Revolutionary War. It is also an important part of the Chinese national spirit. The spirit of Jinggangshan contains the ideological connotation and spiritual outlook of ideals and convictions, hard work and innovation. Under the new historical conditions, how to continue to further promote the spirit of Jinggangshan, give play to the influence of Jinggangshan spirit on the contemporary university students, promote the ideological and political education of university students, and guide the healthy growth of university students is of great significance.
\end{abstract}

\section{Introduction}

The Jinggangshan spirit is an excellent tradition formed by the Communist Party of China during the revolutionary practice of the Agrarian Revolutionary War and an important part of the Chinese national spirit [1]. Strengthening the national spirit education of university students and cultivating the national spirit of university students is an important content and urgent task of ideological and political education in universities. It is of great practical significance for realizing the goal of building a well-off society in an all-round way and the great rejuvenation of the Chinese nation. Under the new historical conditions, how to continue to further promote the spirit of Jinggangshan, give play to the influence of the spirit of the Soviet region on the contemporary university students, promote the ideological and political education of university students, and guide the healthy growth of university students is of great significance.

\section{The educational role of Jinggangshan spirit}

\subsection{Determine the ideals and beliefs of university students}

The Jinggangshan spirit is a revolutionary spirit created by the Communist Party of China. It was born in the Jinggangshan base area during the Agrarian Revolution. The spirit of Jinggangshan is to inherit the excellent red genes, to consolidate the great ideals and beliefs, and to let the red traditions pass on; as General Secretary Xi Jinping visited and greeted the broad masses of cadres and people in Jiangxi, he pointed out that "we must adhere to the new conditions of the times and persist in the pursuit of ideals." Seeking truth from facts is a new road, arduous struggle to overcome difficulties, relying on the masses to seek victory, and let Jinggangshan spirit radiate a new era of light.[2]" These requirements contain the consistent pursuit of value of the Chinese Communist Party, guiding us to inherit the red genes and stimulate The strength of struggle will advance on the new journey of decisively winning a comprehensive well-off society and realizing the great Chinese dream.

University students are the builders and successors of socialism, and they are the main force in the future social development [3]. As a contemporary college student, only by strengthening his ideals and convictions can he stand taller and look farther.

\subsection{Develop a style of hard work}

Hard work is the connotation of the Jinggangshan spirit and the traditional virtue of the Chinese 
nation [4]. Carrying forward the spirit of Jinggangshan and maintaining the style of hard work and struggle can lead the university students to continuously forge ahead and promote scientific development. In all circumstances, university student party members and student cadres must carry forward the spirit of hard struggle, let hard work become a habit, and life is simple. Let university student party members and student cadres do the spiritual model of persisting and carrying forward the arduous struggle, and drive ordinary university students to maintain and carry forward the spirit of hard struggle, so that it truly becomes the campus cultural tradition and the behavior habits of university students.

\subsection{Inspire the spirit of university students to be creative}

Innovation is accustomed to any period of human development. It is the soul of national progress and the inexhaustible motive force for the country to thrive. In university, students can participate in a variety of innovative entrepreneurial projects, sometimes encounter a lot of difficult issues, such as repeated trials did not produce results, university students do not know how to deal with the problems encountered. Then, the spirit of Jinggangshan can let university students understand the truth of struggle for the ideal, and then continue to work hard, face the difficulties bravely, and finally solve the problem.

\section{The Practical Ways of Jinggangshan Spirit in the Process of university Students' Ideological and Political Education}

\subsection{Carry out social practice activities}

Universities can use the combination of theoretical teaching and social practice to strengthen the revolutionary spirit of the Jinggangshan students and the awareness of patriotism education.

Universities have set up ideological and political theory courses such as Mao Zedong Thought and Ideological and Moral Cultivation. In the classroom, teachers can combine the revolutionary spirit of Jinggangshan and the history of the Jinggangshan Revolution to enable university students to further understand the traditional Jinggangshan spirit of the Chinese clan. Strengthen the understanding of university students on the national spirit.

\subsection{Create a red campus culture}

The cultivation of patriotism education for university students is closely linked to the cultural atmosphere. Strengthening the Jinggangshan spirit and patriotism education of university students requires a good campus culture environment. University libraries can open red books and newspapers about the Jinggangshan Revolution. In major festivals, university students are organized to watch movies and TV shows on the Jinggangshan revolutionary theme. Organizing university student party members under the bright red party, revisiting the oath of joining the party, solemn and solemn commitment to spur and encourage party members to keep making progress and courageously strive for the first.

\subsection{Use new media to guide education}

In today's information modernization, more and more university students get information online. Make full use of new media, and advance the new media genes in classroom teaching with the times to realize the integration of ideological and political education theory and red education.

In the campus network platform, you can set up the "Jinggangshan Revolutionary Spirit" or "Red Traditional Education" and other special sections to display the relics of the Jinggangshan revolutionary struggle and the revolutionary history of the old Red Army in the Jinggangshan Revolutionary Base and make it into a propaganda film on the Internet. University students can learn the spirit of self-dedication and selfless dedication of the old Red Army in Jinggangshan base area at any time, thus guiding contemporary university students to establish correct values of life in the pursuit of the value of the revolutionary predecessors. 


\section{Jinggangshan Spirit Should Pay Attention to the Problems in the Process of university Students' Ideological and Political Education}

\subsection{The integration of Jinggangshan spirit and university students' ideological and political courses is not enough}

Patriotism education is one of the important contents of ideological and political courses in universities. It is also the embodiment of patriotism education for university students to inherit and carry forward the revolutionary spirit of Jinggangshan. Integrating Jinggangshan spiritual education into university students' ideological and political courses can make the study of ideological and political courses more intuitive and image. Universities should attach importance to and make full use of the red education such as Jinggangshan spirit to further improve the ideological quality of university students. However, the existing ideological and political course materials lack the content of Jinggangshan red culture; ideological and political teachers are limited by the syllabus during the course of teaching, and the introduction of red culture is insufficient.

\subsection{Jinggangshan spirit guides university students' practical activities to be improved}

Under the guidance of the red culture of Jinggangshan spirit, university students will cultivate a sense of social responsibility of university students, take responsibility, combine these excellent qualities with innovation and entrepreneurship, strengthen the education and practical training of innovation and entrepreneurship, and enable university students to truly succeed in entrepreneurship. At present, many universities have failed to actively integrate various social resources and build a platform for students' innovation and entrepreneurship resources to inherit the spirit of Jinggangshan.

The educational role of the Jinggangshan spirit is enormous. From a realistic point of view, we believe that the modern revelation and significance of Jinggangshan spirit and contemporary university students' ideological and political education require us to further think and study, because the promotion of Jinggangshan spirit and patriotism education is the practical need to build an innovative country. It is an inevitable choice for practicing the theoretical system of socialism with Chinese characteristics and an inherent requirement for the implementation of the scientific development concept in higher education. In recent years, the academic research on Jinggangshan spirit has given more attention, but the research on Jinggangshan spirit is still in its infancy, and there are still many research fields worth exploring and deepening.

\section{Acknowledgements}

This work was financially supported by Harbin University of Commerce Ph.D. Research Startup Project (Grant NO. 14LG32 ).

\section{References}

[1] X.Ma, The scientific development and significance of the spiritual connotation of Jinggangshan in the new era. Journal of Guangdong Second Normal University,vol.38, pp. 67-71, 2018.

[2] I wish the people of all nationalities in the country a healthy and happy auspicious wish to reform and develop the people's life is booming. Renmin Daily, 2017.

[3] W. Deng, Strengthening College Students' Ideological and Political Education, Training Socialist Builders and Successors. College theory front, vol.8, pp.15-16, 2018.

[4] W.Lu, On the traditional virtues of China - diligence and thrift. The arduous struggle to return to the Journal of Liupanshui Teachers College, vol.18, pp. 51-53, 2016. 